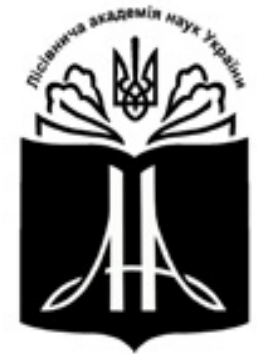

Forestry Academy of Sciences of Ukraine
Наукові праці Лісівничої академії наук України

Proceedings of the Forestry Academy of Sciences of Ukraine http://fasu.nltu.edu.ua

https://doi.org/10.15421/411922

Article received 2018.10.13

Article accepted 2019.03.28
ISSN 1991-606X print

ISSN 2616-5015 online

(a) $\square$ Correspondence author

Volodymyr Mayevskyy

volodymyr_mayevskyy@nltu.edu.ua
General Chuprynka st., 103, Lviv, 79057, Ukraine

УДК 674.214

\title{
Технологічні аспекти регулювання витрат деревинної сировини під час виготовлення віконних блоків з тришарового клеєного бруса
}

\author{
В. О. Маєвський ${ }^{1}$, 3.П. Копинець ${ }^{2}$, В.М. Ковбасюк ${ }^{3}, \in$ М. Миськів ${ }^{4}$, М. М. Якуба ${ }^{5}$
}

На підставі аналізу літературних джерел та власних експериментальних досліджень встановлено, щчо під час виготовлення віконних блоків з тришарового клеєного бруса зі склопакетами значний обсяг відходів деревини утворюється під час профілювання бруса. Аналіз профілів конструкційних елементів віконних блоків $і$ технологічного процесу їхнього виготовлення дав змогу розробити конструкиї тришарових профільних клеєних брусів складного перетину.

Здійснено розрахунки балансів деревинної сировини (сухих обрізних пиломатеріалів) під час виготовлення чотирьох конструкиій віконних блоків розміром $1000 \times 1000$ мм з тришарового клеєного бруса прямокутного перетину та тришарового профільного клеєного бруса складного перетину. За результатами аналізу балансів деревинної сировини під час виготовлення різних конструкцій віконних блоків з'ясовано, щуо частка виходу деталей віконних блоків при використанні тришарового профільного клеєного бруса складного перетину, порівняно з тришаровим клеєним брусом прямокутного перетину, збільшується, зокрема для глухого віконного блоку - від 27,31 до 32,73\%; для віконного блоку, розділеного імпостом на глуху і поворотну стулку - від 22,99 до 29,87\%; для віконного блоку з двома поворотними стулками - від 21,65 до 28, 66\%; для віконного блоку, розділеного імпостом і двома поворотними стулками - від 20,95 до 29,15\%.

Загалом використання тришарового профільного клеєного бруса складного перетину для виготовлення віконних блоків дасть змогу економити до 25,56\% сухих обрізних пиломатеріалів з деревини сосни.

Ключові слова: тришаровий профільний клеєний брус складного перетину; тришаровий клеєний брус прямокутного перетину; баланс деревинної сировини; витрата сухих обрізних пиломатеріалів; вихід деталей віконних блоків.

Маєвський Володимир Олександрович - доктор технічних наук, професор, директор навчально-наукового інституту деревообробних та комп'ютерних технологій і дизайну, професор кафедри технологій лісопиляння, столярних і дерев'яних будівельних виробів. Національний лісотехнічний університет України, вул. генерала Чупринки, 103, м. Львів, 79057, Україна. Тел.: 032-238-44-96, +38-067-670-38-87. E-mail: volodymyr_mayevskyy@nltu.edu.ua ORCID: http://orcid.org/0000-0001-5820-9454.

2 Копинеиь Зоя Павлівна - кандидат технічних наук, доцент кафедри технологій лісопиляння, столярних і дерев'яних будівельних виробів. Національний лісотехнічний університет України, вул. генерала Чупринки, 103, м. Львів, 79057, Україна. Тел.: +38-067670-20-58. E-mail: zoya_kopynets@nltu.edu.ua ORCID: http://orcid.org/0000-0001-8977-6953.

3 Ковбасюк Володимир Михайлович - заступник технічного директора. ТОВ фірма «Будсервіс» ЛТД, вул. Бродівська, 48, м. Тернопіль, 46019, Україна. Тел.: +38-098-829-40-35. E-mail: haose1990@gmail.com.

4 Миськів Свстахій Михайлович - кандидат технічних наук, старший викладач кафедри технологій лісопиляння, столярних і дерев'яних будівельних виробів. Національний лісотехнічний університет України, вул. генерала Чупринки, 103, м. Львів, 79057, Україна. Тел.: +38-067-406-03-96. E-mail: myskivs@i.ua ORCID: http://orcid.org/0000-0003-1762-4728.

Якуба Мирослава Михайлівна - старший викладач кафедри економіки підприємства. Національний лісотехнічний університет України, вул. генерала Чупринки, 103, м. Львів, 79057, Україна. Тел.: +38-067-267-91-88. E-mail: myroslavaya@gmail.com ORCID: http:// orcid.org/0000-0001-8871-2392. 
Вступ. Вибір віконних блоків, виготовлених 3 деревини або полівінілхлориду (ПВХ), та їхне порівняння за різними ознаками, є дискусійним питанням впродовж останніх десятиліть. Дерев'яні віконні блоки мають низку переваг над віконними блоками з ПВХ. До таких основних переваг відносять естетичність, оскільки якісно відтворити неповторну природну красу деревини штучним способом досі не вдалося, та екологічність - деревина екологічно чистий відновлюваний матеріал, а вплив хімічних речовин для оброблення деревини - мізерний, тому утилізація дерев'яних віконних блоків після завершення терміну їхньої експлуатації не викликає труднощів. Натомість найближчим часом постане гостра проблема утилізації віконних блоків з ПВХ, позаяк на цей час немає ефективних і безпечних способів утилізації ПВХ, а процес його спалювання супроводжується викидами небезпечних хімічних речовин у навколишнє середовище (Thompson, 2005).

Для виготовлення сучасних дерев'яних віконних блоків використовують тришарові клеєні бруси (термін «брус» умовний, позаяк поперечний перетин цих брусів, зазвичай, менше 100×100 мм). Основними причинами виготовлення віконних блоків саме 3 тришарових клеєних брусів, а не 3 цільних, є те, що забезпечити якісне сушіння тонких пиломатеріалів (заготовок) технологічно простіше, ніж товстих. Окрім цього, для видимої поверхні завжди можна відібрати якісніші заготовки, а ті, що 3 допустимими вадами, - використати для середнього шару. Заготовки можна сортувати за низкою критеріїв, тому неважко добитися, щоб і виготовлені 3 них віконні блоки були однорідної якості (Report on research work, 2006, Myskiv et al., 2007). Клеєні бруси порівняно з цільною деревиною, за дотримання технології їхнього виготовлення та належної експлуатації, мають вищу міцність (Kurowska \& Kozakiewicz, 2010, Koshyrets \& Gryciuk, 2010) та формостійкість (Pardaev, 2008).

Розвиток виробництва віконних блоків з ПВХ в Україні призвів до зростання конкуренції на ринку віконних блоків (Official site State Statistics Service of Ukraine). Вітчизняним виробникам віконних блоків 3 тришарових клеєних брусів зі склопакетами для зміцнення своїх позицій на ринку потрібно шукати шляхи здешевлення своєї продукції.

Поперечний перетин елементів сучасних віконних блоків має складний профіль (Ferents \& Maksymiv, 2011, Brauzevetter \& Brauzevetter, 2005), який найчастіше отримують шляхом фрезерування тришарових клеєних брусів прямокутного перетину (Report on research work, 2006, Ferents \& Maksymiv, 2011), тому витрати деревини на виготовлення віконних блоків встановлюють для умов використання саме таких брусів (Guiding technical and economic materials, 1988, Maksymiv et al., 2009). Проте у нормативних документах (DSTU B V.2.624-2001) та закордонних джерелах (Volynskii \& Plastinin, 2005) пропонують для зменшення витрати деревини використовувати профільні бруси L, T та $\mathrm{Z}$ перетинів, розміри яких відповідають поперечно- му перетину профілів елементів віконних блоків 3 припусками на механічну обробку.

Недоліками під час використання тришарових клеєних брусів прямокутного перетину для виготовлення елементів віконних блоків є витрати деревини у стружку $(22,70 \ldots 69,12 \%)$ (Mayevskyy et al., 2017), значні витрати енергіï, перенавантаження інструмента і шпиндельних вузлів стругальних верстатів під час профілювання. Використання брусів L, T та Z перетинів усуває зазначені недоліки не повністю (Kopynets et al., 2017).

Отже, актуальним напрямком досліджень $є$ розроблення та впровадження у виробництво нових перспективних конструкцій тришарових клеєних брусів, зокрема профільних, які враховують форму елементів віконних блоків.

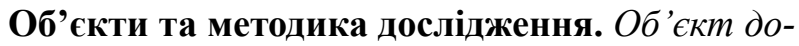
слідження - віконні блоки з тришарових клеєних брусів. Предмет дослідження - технологічний процес виготовлення тришарових профільних клеєних брусів складного перетину та розрахунок і аналіз балансів деревинної сировини під час виготовлення віконних блоків з тришарових клеєних брусів. $\mathrm{Me}$ тою роботи є розроблення напрямів економії деревинної сировини під час виготовлення віконних блоків з тришарових клеєних брусів.

Для досягнення поставленої мети проведено низку експериментальних досліджень у виробничих умовах (Mayevskyy et al., 2017), результати яких засвідчили, що значні обсяги відходів деревини утворюються під час профілювання бруса, коли високоякісна деревина переводиться у стружку. Для економії деревинної сировини розроблено конструкції тришарових профільних клеєних брусів складного перетину для виготовлення віконних блоків із склопакетами (Kopynets et al., 2017).

Аналіз профілів конструкційних елементів віконних блоків та технологічного процесу на ТОВ фірма «Будсервіс» ЛТД (м. Тернопіль) дав змогу розробити конструкції тришарових профільних клеєних брусів складного перетину для ї виготовлення в умовах цього підприємства. Запропоновано виготовляти заготовки різної ширини і склеювати ïх в такі бруси (рис. 1) (Kopynets et al., 2017).

Під час формування тришарових профільних клеєних брусів складного перетину для їх фіксації в упорах потрібно виготовити шаблони. Для забезпечення якісного склеювання цих брусів, враховуючи граничні відхилення під час виготовлення заготовок, шаблони доцільно виготовляти 3 еластичного матеріалу - листа гуми завтовшки 10 мм (рис. 2). Варіант комплекту заготовок для профілю стулки наведено на рис. 3.

Варто акцентувати увагу на відмінностях технологій виготовлення віконних блоків 3 тришарових клеєних брусів прямокутного та профільних складних перетинів. Пакет для пресування тришарових профільних брусів складних перетинів формували так: поміщали найширшу заготовку між упори фронтальної фіксації вайми; далі на одну пласть середньої заготовки наносили клей і поміщали іiі 
між упори фронтальної фіксації вайми, базуючи за допомогою шаблона; далі на одну пласть третьої заготовки наносили клей і поміщали їі між упори фронтальної фіксації вайми, базуючи за допомогою шаблона (рис. 4 і 5). Сформовані бруси затискали у ваймі і починали процес пресування.

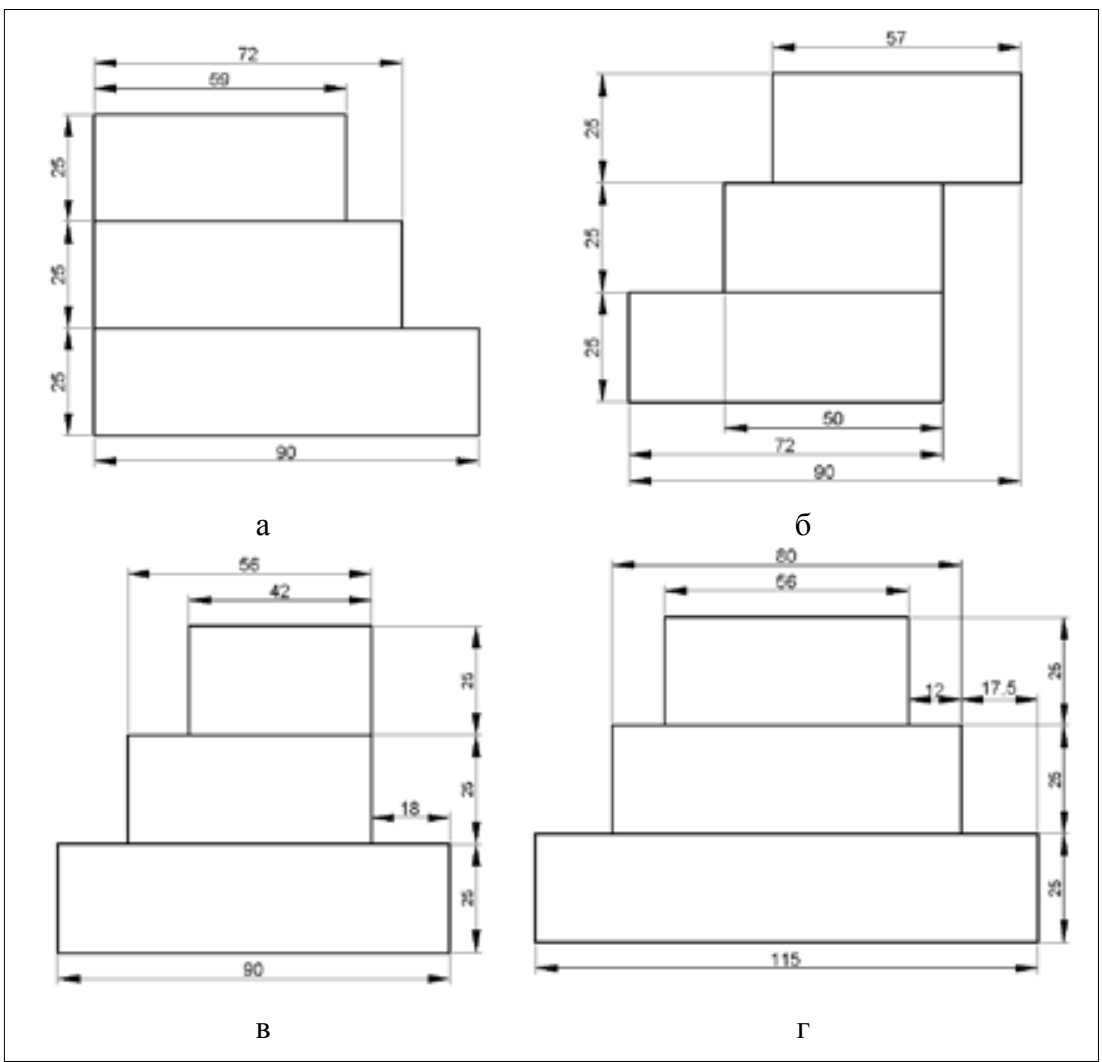

Рис. 1. Поперечний перетин тришарових профільних клеєних брусів складного перетину: $\mathrm{a}$ - для коробки; б - для стулки; в - для імпоста; г - для імпоста широкого

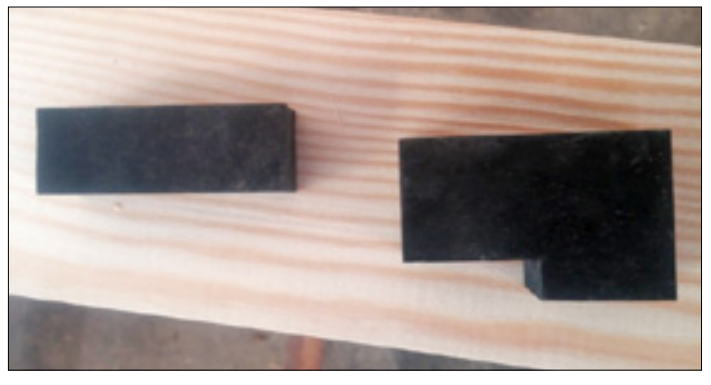

Рис. 2. Зразки гумових шаблонів

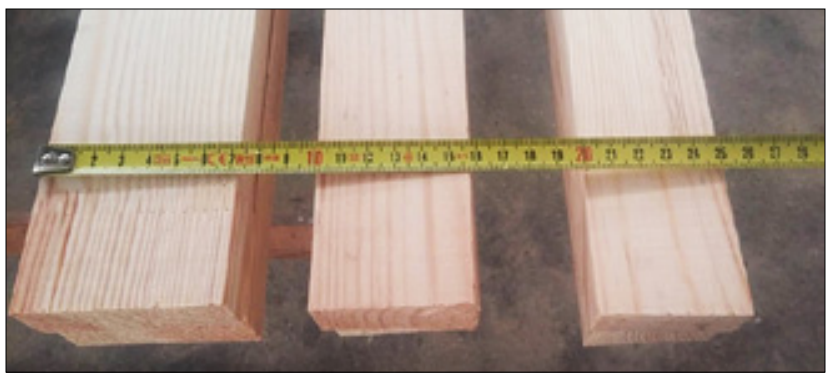

Рис. 3. Заготовки для профілю стулки
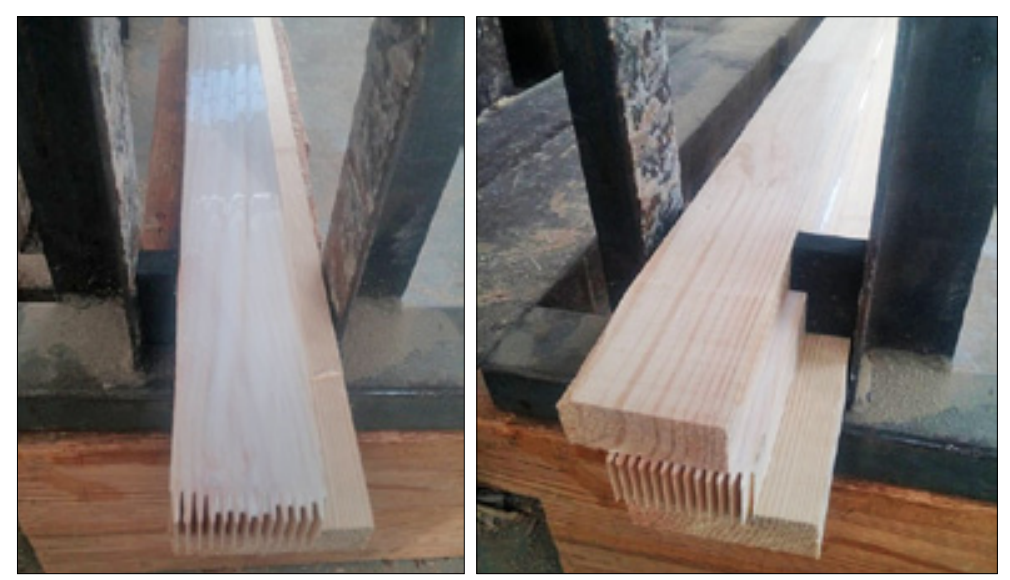

Рис. 4. Процес формування тришарового профільного клеєного бруса складного перетину

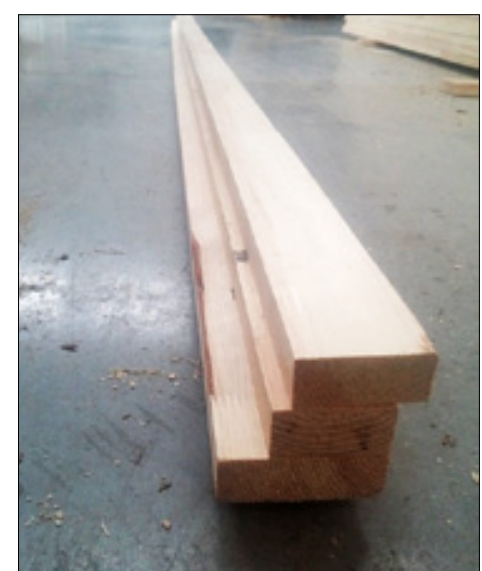

Рис. 5. Тришаровий профільний клеєний брус складного перетину для стулки 
Результати дослідження. На підставі здійснених експериментів та результатів їхньої обробки, для прикладу, розраховано та наведено баланси деревинної сировини (соснових сухих обрізних пиломатеріалів) для чотирьох конструкцій віконних блоків розміром 1000×1000 мм (табл. 1). Конструкції віконних блоків, для яких проводили розрахунки, наведено на рис. 6 .
У глухому віконному блоці (№ 1) склопакет закріплено в коробці із внутрішнім профілем як у стулки. У віконному блоці, розділеному імпостом на глуху і поворотну стулку (№ 2), склопакет у глухій стулці знизу і зверху додатково закріплено за допомогою фіксуючого бруска та заповнюючої рейки відповідно.

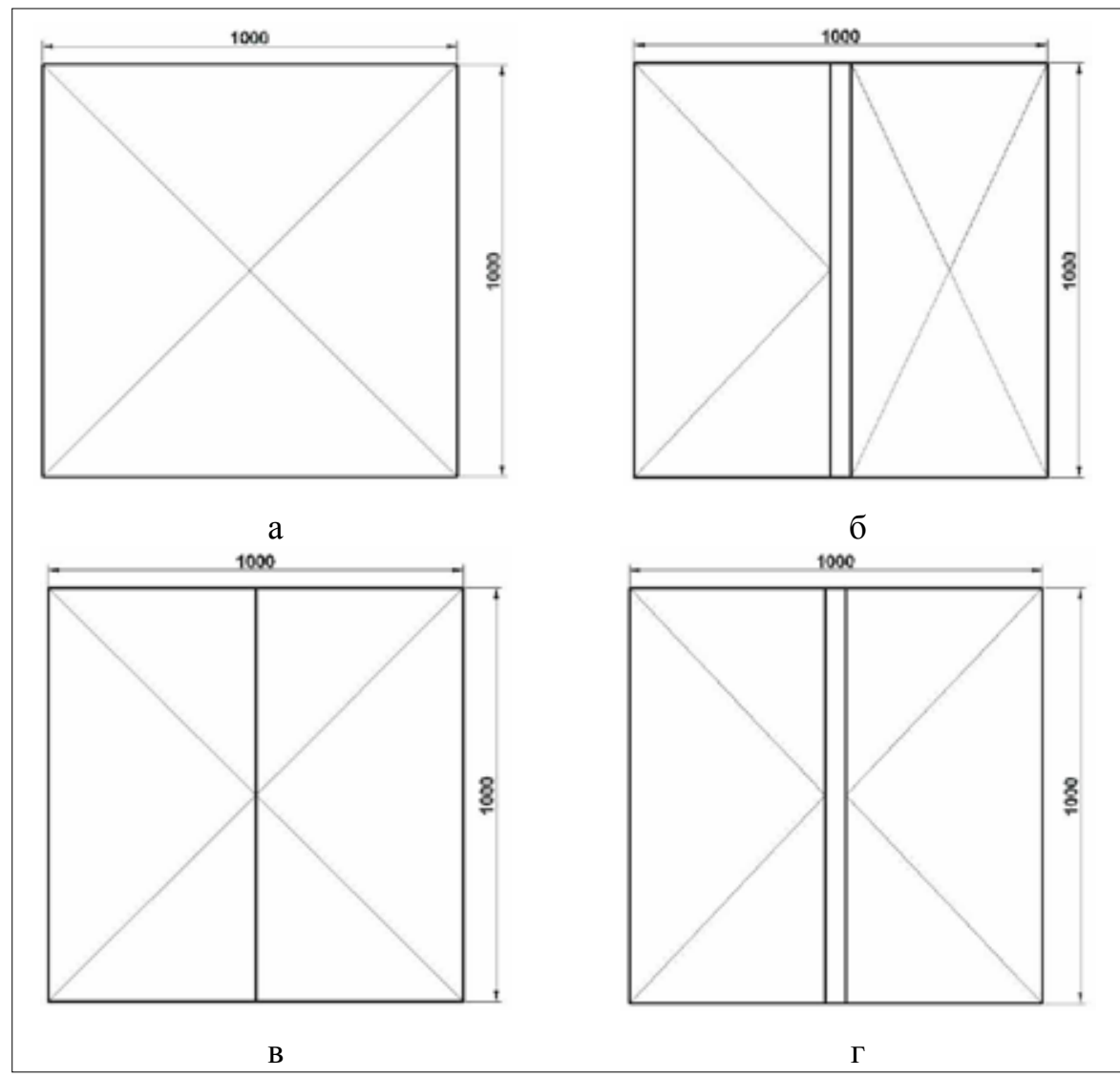

Рис. 6. Конструкції віконних блоків, для яких проводили розрахунки: а - № 1 (глухий віконний блок); б - № 2 (віконний блок, розділений імпостом на глуху і поворотну стулку); в - № 3 (віконний блок 3 двома поворотними стулками); г - № 4 (віконний блок, розділений імпостом і двома поворотними стулками)

Таблиия 1

Баланси деревинної сировини (соснових сухих обрізних пиломатеріалів) під час виготовлення віконних блоків з тришарових клеєних брусів прямокутного перетину

\begin{tabular}{|c|c|c|c|c|c|c|c|c|c|}
\hline \multirow{4}{*}{$\begin{array}{l}\underset{m}{E} \\
\text { 竞 }\end{array}$} & \multirow{4}{*}{ Стаття балансу } & \multicolumn{8}{|c|}{ № віконного блоку } \\
\hline & & \multicolumn{2}{|r|}{1} & \multicolumn{2}{|r|}{2} & \multicolumn{2}{|c|}{3} & \multicolumn{2}{|c|}{4} \\
\hline & & \multicolumn{8}{|c|}{ Кількість } \\
\hline & & $\%$ & $\begin{array}{c}\text { м }^{3} \text { на } \\
\text { віконний } \\
\text { блок }\end{array}$ & $\%$ & $\begin{array}{c}\text { м }^{3} \text { на } \\
\text { віконний } \\
\text { блок }\end{array}$ & $\%$ & $\begin{array}{c}\mathrm{M}^{3} \text { на } \\
\text { віконний } \\
\text { блок }\end{array}$ & $\%$ & $\begin{array}{c}\mathrm{M}^{3} \text { на } \\
\text { віконний } \\
\text { блок }\end{array}$ \\
\hline 1 & Віконний блок & 27,31 & 0,015141 & 22,99 & 0,024455 & 21,65 & 0,027399 & 20,95 & 0,029829 \\
\hline 2 & Тирса & 2,87 & 0,001590 & 2,87 & 0,003060 & 2,87 & 0,003630 & 2,87 & 0,004080 \\
\hline 3 & Кускові відходи & 28,11 & 0,015580 & 28,11 & 0,029910 & 28,11 & 0,035600 & 28,11 & 0,040020 \\
\hline 4 & Стружка & 41,68 & 0,023110 & 46,01 & 0,048950 & 47,35 & 0,059950 & 48,05 & 0,068400 \\
\hline 5 & Шліфувальний порох & 0,03 & 0,000015 & 0,02 & 0,000024 & 0,02 & 0,000029 & 0,02 & 0,000023 \\
\hline & $\begin{array}{l}\text { Сировина (соснові сухі } \\
\text { обрізні пиломатеріали) }\end{array}$ & 100 & 0,055436 & 100 & 0,106399 & 100 & 0,126608 & 100 & 0,142352 \\
\hline
\end{tabular}


Як випливає із наведених в табл. 1 даних, відсоткове співвідношення статей балансу залежить від конструкції віконного блоку. Відсоткове співвідношення статей балансу також буде змінюватися за зміни розмірів віконних блоків.

Порівняння балансів деревинної сировини (соснових сухих обрізних пиломатеріалів) під час виготовлення вказаних типів віконних блоків 3 тришарових клеєних брусів прямокутного перетину наведено на рис. 7.

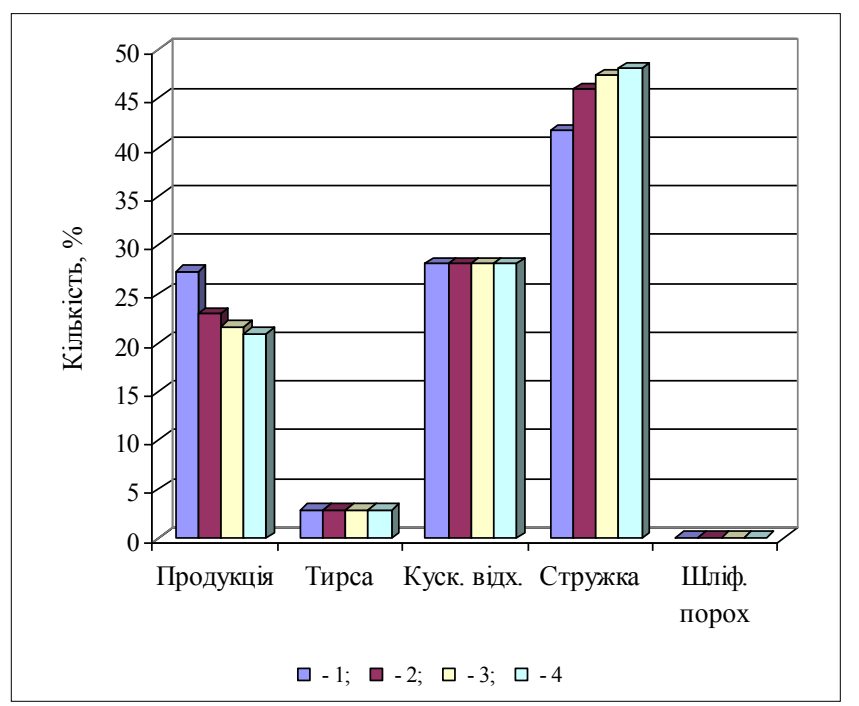

Рис. 7. Порівняння балансів деревинної сировини під час виготовлення віконних блоків з тришарових клеєних брусів прямокутного перетину: 1 - для типу віконного блоку № $1 ; 2$ - для типу віконного блоку № 2; 3 - для типу віконного блоку № $3 ; 4$ - для типу віконного блоку № 4

Результати аналізу балансів деревинної сировини для різних конструкцій віконних блоків свідчать, що зі збільшенням кількості конструкційних елементів зростають витрати в стружку.

Розрахунки балансів деревинної сировини для чотирьох конструкцій віконних блоків розміром
$1000 \times 1000$ мм 3 тришарових профільних клеєних брусів, наведених на рис. 6 , зведено в табл. 2 .

Порівняння балансів деревинної сировини під час виготовлення різних конструкцій віконних блоків 3 тришарових профільних клеєних брусів складного перетину та тришарових клеєних брусів прямокутного перетину наведено на рис. 8-11.

Результати аналізу балансів деревинної сировини (сухих обрізних пиломатеріалів) під час виготовлення різних конструкцій віконних блоків свідчать, що відсоток виходу деталей віконних блоків у разі застосування тришарових профільних клеєних брусів складного перетину, порівняно 3 тришаровими клеєними брусами прямокутного перетину збільшується, зокрема для віконного блоку № 1 від 27,31 до $32,73 \%$ (див. рис. 8 ), для віконного блоку № 2 - від 22,99 до 29,87\% (див. рис. 9), для віконного блоку № 3 - від 21,65 до 28,66\% (див. рис. 10), для віконного блоку № 4 - від 20,95 до $29,15 \%$ (див. рис. 11 ).

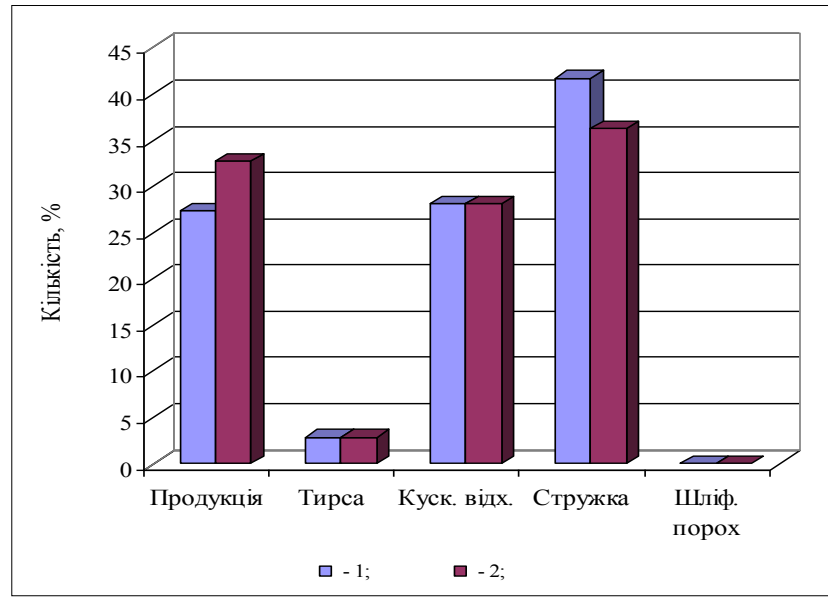

Рис. 8. Порівняння балансів деревинної сировини під час виготовлення віконного блоку № 1:

$1-3$ тришарових клеєних брусів прямокутного перетину; 2 - 3 тришарових профільних клеєних брусів складного перетину

Таблиия 2

Баланси деревинної сировини (соснових сухих обрізних пиломатеріалів) під час виготовлення віконних блоків з тришарових профільних клеєних брусів складного перетину

\begin{tabular}{|c|c|c|c|c|c|c|c|c|c|}
\hline \multirow{4}{*}{$\begin{array}{l}\underset{N}{F} \\
\text { 竞 }\end{array}$} & \multirow{4}{*}{ Стаття балансу } & \multicolumn{8}{|c|}{ № віконного блоку } \\
\hline & & \multicolumn{2}{|r|}{1} & \multicolumn{2}{|r|}{2} & \multicolumn{2}{|c|}{3} & \multicolumn{2}{|r|}{4} \\
\hline & & \multicolumn{8}{|c|}{ Кількість } \\
\hline & & $\%$ & $\begin{array}{c}\mathrm{M}^{3} \text { на } \\
\text { віконний } \\
\text { блок }\end{array}$ & $\%$ & $\begin{array}{c}\mathrm{M}^{3} \text { на } \\
\text { віконний } \\
\text { блок }\end{array}$ & $\%$ & $\begin{array}{c}\mathrm{M}^{3} \text { на } \\
\text { віконний } \\
\text { блок }\end{array}$ & $\%$ & $\begin{array}{l}\mathrm{M}^{3} \text { на } \\
\text { віконний } \\
\text { блок }\end{array}$ \\
\hline 1 & Віконний блок & 32,73 & 0,015141 & 29,87 & 0,024455 & 28,66 & 0,027399 & 28,15 & 0,029829 \\
\hline 2 & Тирса & 2,87 & 0,001330 & 2,87 & 0,002350 & 2,87 & 0,002740 & 2,87 & 0,003040 \\
\hline 3 & Кускові відходи & 28,11 & 0,013000 & 28,11 & 0,023020 & 28,11 & 0,026870 & 28,11 & 0,029790 \\
\hline 4 & Стружка & 36,26 & 0,016770 & 39,12 & 0,032030 & 40,33 & 0,038550 & 40,84 & 0,043270 \\
\hline \multirow[t]{2}{*}{5} & Шліфувальний порох & 0,03 & 0,000014 & 0,03 & 0,000025 & 0,03 & 0,000029 & 0,03 & 0,000032 \\
\hline & $\begin{array}{l}\text { Сировина (соснові сухі } \\
\text { обрізні пиломатеріали) }\end{array}$ & 100 & 0,046260 & 100 & 0,081880 & 100 & 0,095590 & 100 & 0,105960 \\
\hline
\end{tabular}




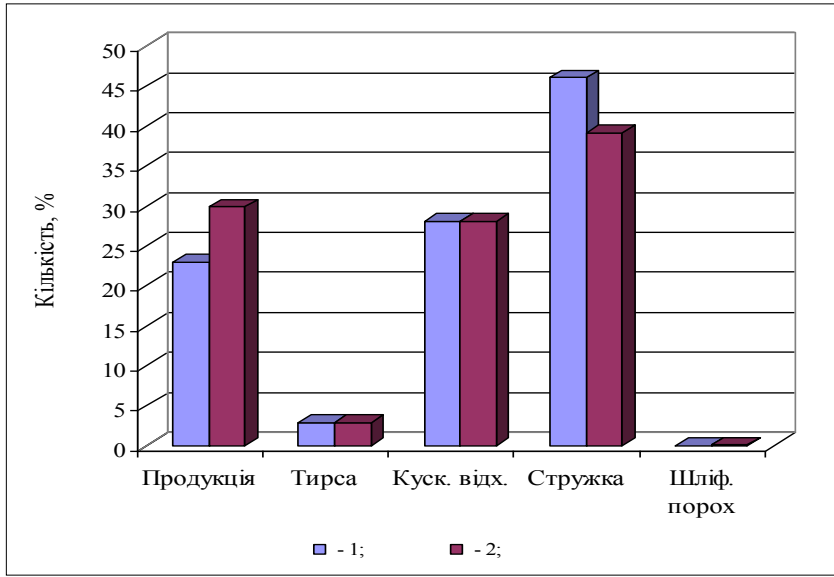

Рис. 9. Порівняння балансів деревинної сировини під час виготовлення віконного блоку № 2:

$1-3$ тришарових клеєних брусів прямокутного перетину; 2 - 3 тришарових профільних клеєних брусів складного перетину

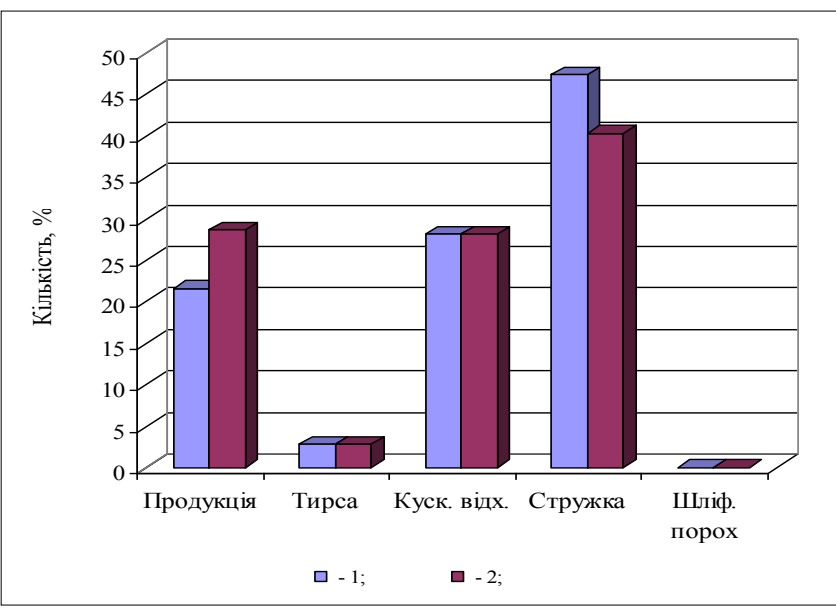

Рис. 10. Порівняння балансів деревинної сировини під час виготовлення віконного блоку № 3 :

1 - 3 тришарових клеєних брусів прямокутного перетину; 2 - 3 тришарових профільних клеєних брусів складного перетину

Порівняння витрати сухих обрізних пиломатеріалів на виготовлення 1000 шт. віконних блоків розміром $1000 \times 1000$ мм чотирьох аналізованих конструкцій за умови використання тришарових профільних клеєних брусів складного перетину та тришарових клеєних брусів прямокутного перетину наведено на рис. 12.

На 1000 шт. віконних блоків № 1 у разі використання тришарових клеєних брусів прямокутного перетину потрібно 55,44 м³ сухих обрізних пиломатеріалів, а за використання тришарових профільних клеєних брусів складного перетину - 46,25 м³ , економія становить $16,58 \%$; для віконних блоків № $2-$ відповідно 106,40 та 81,89 м³, економія - 23,04\%; для віконних блоків № 3 - відповідно 126,61 та 95,59 м², економія - 24,50\%; а для віконних блоків № 4 - відповідно 142,35 та 105,96 м $^{3}$, економія - 25,56\%.

Висновки. Запропоновано варіант технології виготовлення тришарових профільних клеєних брусів складного перетину, який апробовано у виробничих умовах. Реалізація такого варіанту дасть змогу усунути зайві витрати високоякісної деревини під час профілювання тришарових клеєних брусів прямокутного перетину.

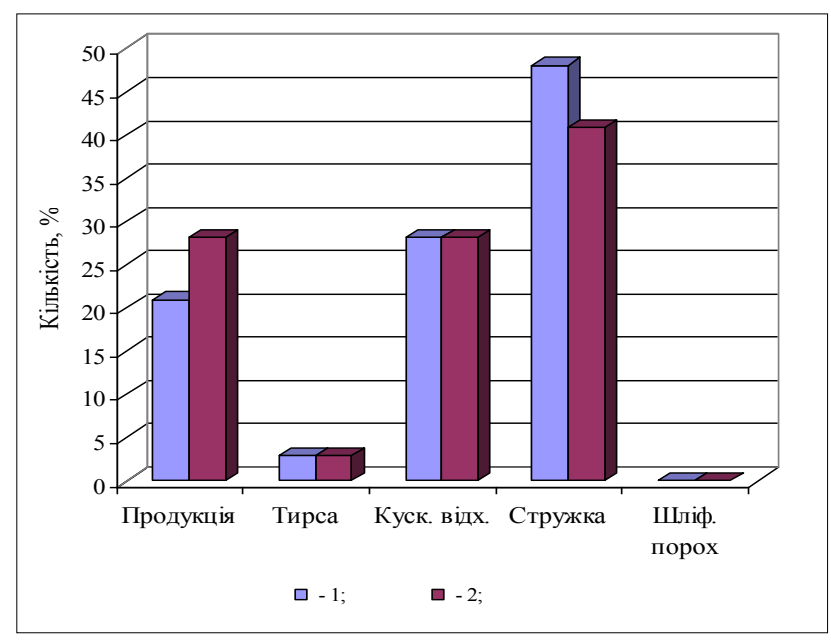

Рис. 11. Порівняння балансів деревинної сировини під час виготовлення віконного блоку № 4:

$1-3$ тришарових клеєних брусів прямокутного перетину; 2 - 3 тришарових профільних клеєних брусів складного перетину

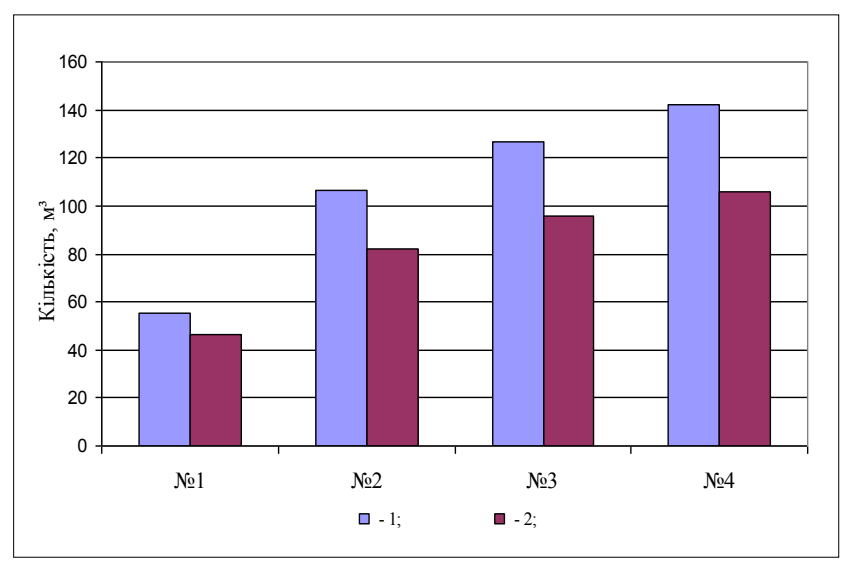

Рис. 12. Порівняння витрати сухих обрізних пиломатеріалів на виготовлення 1000 шт. віконних блоків $1000 \times 1000$ мм чотирьох конструкцій: 1 - 3 тришарових клеєних брусів прямокутного перетину; 2 - 3 тришарових профільних клеєних брусів складного перетину

Розраховано баланси деревинної сировини (соснових сухих обрізних пиломатеріалів) під час виготовлення чотирьох конструкцій віконних блоків 3 тришарових профільних клеєних брусів складного перетину та тришарових клеєних брусів прямокутного перетину. За результатами порівняльного аналізу цих балансів з'ясовано, що відсоток виходу деталей віконних блоків при застосуванні тришарових профільних клеєних брусів складного перетину порівняно 3 тришаровими клеєними брусами прямокутного перетину, збільшується, зокрема: для глухого віконного блоку - від 27,31 до $32,73 \%$; для віконного блоку, розділеного імпостом на глуху і поворотну стулку - від 22,99 до 29,87\%; для віконного 
блоку 3 двома поворотними стулками - від 21,65 до $28,66 \%$; для віконного блоку, розділеного імпостом і двома поворотними стулками - від 20,95 до 29,15 \%.

\section{Бібліографічні посилання}

Brauzevetter, Yu., \& Brauzevetter, N. (2005). Wooden windows: arguments and facts. In Wooden Eurowindows. Thematic newsletter to the newspaper «Derevoobrobnyk» (pp. 2-5). Lviv, Ukraine: «Editorial office of the newspaper»" Derevoobrobnyk», LLC (in Ukrainian).

DSTU B V.2.6-24-2001 (GOST 24700-99) (2001) Constructions of building and structures. Windows of wood with glassing units. Specifications. Edition is official. Kyiv: State Committee for Construction, Architecture and Residential Policy of Ukraine (in Ukrainian, in Russian).

Ferents, O.B., \& Maksymiv, V.M. (2011). Technology of joiner's products. Lviv: Ukrainian National Forestry University (in Ukrainian).

Guiding technical and economic materials on the standardization of the consumption of materials in the manufacture of joinery-building products (1988). Balabanovo,USSR:USPA «Soyuznauchstandartdom» USSR Forestry Ministry (in Russian).

Kopynets, Z. P., Kovbasiuk, V. M., Bezkorovainyi, A. H., Mayevskyy, V. O., \& Ferents, O. B. (2017). Structures of three-layer shaped bars for the manufacture of windows with glassing units. Patent № 119868 of Ukraine (In Ukrainian).

Koshyrets, S. I., \& Gryciuk, Yu. I. (2010). Analysis of technologies of making of pur-veyances of the glued squared beam is for necessities of joiner's production. Scientific Bulletin of the Ukrainian National Forestry University, 20.2, 87-92 (in Ukrainian).

Kurowska, A., \& Kozakiewicz, P. (2010). Density and shear strength as solid wood and glued laminated timber suitability criterion for window woodwork manufacturing. Forestry and Wood Technology, 71, 429-434.

Maksymiv, V.M., Ferents, O.B., \& Kopynets, Z.P. (2009). Improving the efficiency of the use of forest resources in the production of joinery-building products, vol. 2, (pp. 250-253). Minsk, Belarus: BSTU (in Russian).

Mayevskyy, V. O., Kopynets, Z.P., Myskiv, Y.M., \& Kovbasiuk, V.M. (2017). Estimation of wood waste amount in the manufacture of window unit from a three-layer glued bar. Forestry, Forest, Paper and Woodworking Industry, 43, 46-52 (in Ukrainian).

Myskiv, Ye. M., Mayevskyy, V.O., \& Maksymiv, V. M. (2007). Basic directions of researches of technological process of making of the glued squared beam. Scientific Bulletin of the Ukrainian National Forestry University, 17.1, 118-122 (in Ukrainian).

Official site of the State Statistics Service of Ukraine. Retrieved from http://www.ukrstat.gov.ua/operativ/ operativ2016/pr/vr_rea_ovpp/vr_rea_ovpp_u/arh vppv_u.html
Pardaev, A.S. (2008). Ensuring the shape stability of inhomogeneous solid wood, taking into account the cylindrical anisotropy of its elements during drying and swelling (Doctoral dissertation, Belarusian State Technological University, Minsk, Belarus). Retrieved from http://dep.nlb.by/jspui/handle/nlb/23926 (in Russian).

Report on research work «To develop science-based norms of wood consumption in the manufacture of joinery-building products» (2006). (Contract No. 08. 24-10-06). Lviv, Ukraine: Ukrainian National Forestry University (in Ukrainian).

Thompson, C. (2005). Window of opportunity. The environmental and economic benefits of specifying timber window frames. WWF-UK, July, 27.

Volynskii, V.N., \& Plastinin, S.N. (2005). Primary processing of sawn timber at sawmills. Moscow: Riel-press (in Russian).

\section{Технологические аспекты регулирования расхода древесного сырья при изготовлении оконных блоков из трехслойного клееного бруса}

\author{
В. О. Маевский ${ }^{1}$, 3. П. Копинец ${ }^{2}$, В.М. Ковбасюк \\ Е. М. Мыськив ${ }^{4}$, М. М. Якуба ${ }^{5}$
}

На основании литературных источников и собственных экспериментальных исследований установлено, что при изготовлении оконных блоков

Маевский Володымыр Олэксандрович - доктор технических наук, профессор, директор учебно-научного института деревообрабатывающих и компьютерных технологий и дизайна, профессор кафедры технологий лесопиления, столярных и деревянных строительных изделий. Национальный лесотехнический университет Украины, ул. генерала Чупринки, 103, г. Львов, 79057, Украина. Тел.: 032-238-44-96, +38-067670-38-87. E-mail: volodymyr mayevskyy@nltu.edu.ua ORCID: http://orcid.org/0000-0001-5820-9454.

Копинец Зоя Павловна - кандидат технических наук, доцент кафедры технологий лесопиления, столярных и деревянных строительных изделий. Национальный лесотехнический университет Украины, ул. генерала Чупринки, 103, г. Львов, 79057, Украина. Тел.: +38-067-670-20-58. E-mail: zoya_kopynets@nltu. edu.ua ORCID: http://orcid.org/0000-0001-8977-6953.

Ковбасюк Володымыр Михайлович - заместитель технического директора. ООО фирма «Будсервис» ЛТД, ул. Бродивська, 48, г. Тернополь, 46019, Украина. Тел.: +38-098-829-40-35. E-mail: haose1990@gmail.com.

4 Мыськив Евстахий Михайлович - кандидат технических наук, старший преподаватель кафедры технологий лесопиления, столярных и деревянных строительных изделий. Национальный лесотехнический университет Украины, ул. генерала Чупринки, 103, г. Львов, 79057, Украина. Тел.: +38-067-406-03-96. E-mail: myskivs@i.ua ORCID: http://orcid.org/0000-0003-1762-4728.

Якуба Мирослава Михайловна - старший преподаватель кафедры экономики предприятия. Национальный лесотехнический университет Украины, ул. генерала Чупринки, 103, г. Львов, 79057, Украина. Тел.: +38-067-267-91-88. E-mail: myroslavaya@, gmail.com ORCID: http://orcid.org/0000-0001-8871-2392. 
из трехслойного клееного бруса со стеклопакетами значительный объем отходов древесины образуется при профилировании бруса. Анализ профилей конструкционных элементов оконных блоков и технологического процесса их изготовления позволил разработать конструкции трехслойных профильных брусьев сложного сечения. Разработаны конструкции трехслойных профильных клееных брусьев сложного сечения для изготовления брусков коробки, створки и импостов.

Существуют незначительные различия технологий изготовления трехслойных клееных брусьев прямоугольного и профильного сложных сечений. В частности, при формировании трехслойных профильных клееных брусьев сложного сечения для их фиксации в упорах целесообразно изготавливать шаблоны из эластичного материала. Это важно для обеспечения качественного склеивания этих брусьев, учитывая предельные отклонения при изготовлении заготовок.

На основании проведенных экспериментальных исследований и результатов их обработки, как пример, выполнены расчеты балансов древесины (сухих обрезных пиломатериалов) при изготовлении четырех конструкций оконных блоков размером $1000 \times 1000$ мм с трехслойного клееного бруса прямоугольного сечения и трехслойного профильного клееного бруса сложного сечения.

Расчеты проведены для таких конструкций: глухой оконный блок; оконный блок, разделенный импостом на глухую и поворотную створку; оконный блок с двумя поворотными створками; оконный блок, разделенный импостом и двумя поворотными створками. В глухом оконном блоке стеклопакет закреплен в коробке с внутренним профилем как в створке. В оконном блоке, разделенном импостом на глухую и поворотную створку, стеклопакет в глухой створке снизу и сверху дополнительно закреплен с помощью фиксирующего бруска и заполняющей рейки соответственно.

По результатам анализа балансов древесины (сухих обрезных пиломатериалов) при изготовлении различных конструкций оконных блоков установлено, что процент выхода деталей оконных блоков с использованием трехслойного профильного клееного бруса сложного сечения, по сравнению с трехслойным клееным брусом прямоугольного сечения, увеличивается, в частности: для глухого оконного блока - от 27,31 до $32,73 \%$; для оконного блока, разделенного импостом на глухую и поворотную створку - от 22,99 до $29,87 \%$; для оконного блока с двумя поворотными створками - от 21,65 до $28,66 \%$; для оконного блока, разделенного импостом и двумя поворотными створками - от 20,95 до $29,15 \%$.

В общем, использование трехслойного профильного клееного бруса сложного сечения для изготовления оконных блоков позволит экономить до $25,56 \%$ сухих обрезных пиломатериалов из древесины сосны.
Ключевые слова: трехслойный профильный клееный брус сложного сечения; трехслойный клееный брус прямоугольного сечения; баланс древесного сырья; расход сухих обрезных пиломатериалов; выход деталей оконных блоков.

\section{Technological aspects of raw wood material consumption regulation in the manufacture of window units from three-layer glued bars}

\author{
V. Mayevskyy ${ }^{1}$, Z. Kopynets ${ }^{2}$, V. Kovbasyuk ${ }^{3}$, \\ Ye. Myskiv ${ }^{4}$, M. Yakuba
}

On the basis of literature sources analysis and our experimental studies it was found that during the manufacture of window units from three-layer glued bars with double-glazed windows, a significant amount of wood waste is produced during the bar shaping. The analysis of the profiles of structural elements of window units and the technological process of their manufacture made it possible to develop the structure of three-layer shaped glued bar of complex cross-section. Designs of three-layer shaped glued bars of complex cross-section for the manufacture of the window frame, window leafs and transom-bars have been developed.

There are insignificant differences in the manufacturing techniques of three-layer glued bars of rectangular and shaped complex cross-sections. In particular, when forming three-layer shaped glued bars of a complex cross-section, to hold them in the stops, it is necessary to make templates from elastic material.

Volodymyr Mayevskyy - Doctor of Sciences, Professor, Director of Educational-Scientific Institute of Woodworking and Computer Technologies and Design, Professor of Department of Saw-Milling, Joinery and Wooden Building Products. Ukrainian National Forestry University.103 General Chuprynka st., Lviv, 79057, Ukraine. Tel.: 032-238-44-96, +38-067-670-38-87. E-mail: volodymyr mayevskyy@nltu.edu.ua ORCID: http://orcid.org/0000-00015820-9454.

2 Zoya Kopynets - PhD in Technical Sciences, Associate Professor of Department of Saw-Milling, Joinery and Wooden Building Products. Ukrainian National Forestry University.103 General Chuprynka st., Lviv, 79057, Ukraine. Tel.: +38-067-670-2058. E-mail: zoya_kopynets@nltu.edu.ua ORCID: http://orcid. org/0000-0001-8977-6953.

3 Volodymyr Kovbasiuk - Deputy Technical Director. Limited Liability Company BUDSERVIS LTD, Brodivska st, 48, Ternopil, 46019, Ukraine. Tel.: +38-098-829-40-35. E-mail: haose1990@, gmail.com.

4 Yevstakhii Myskiv - PhD in Technical Sciences, Senior teacher of Department of Saw-Milling, Joinery and Wooden Building Products. Ukrainian National Forestry University.103 General Chuprynka st., Lviv, 79057, Ukraine. Tel.: +38-067-406-03-96. E-mail: myskivs@i.ua ORCID: http://orcid.org/0000-0003-1762-4728.

Myroslava Yakuba - Senior teacher of Department Economy of the Enterprise. Ukrainian National Forestry University.103 General Chuprynka st., Lviv, 79057, Ukraine. Tel.: +38-067-267-91-88. E-mail: myroslavaya@gmail.com ORCID: http://orcid.org/00000001-8871-2392. 
This is important for ensuring good adhesion of these bars, taking into consideration the tolerances during the manufacture of the blanks.

On the basis of the conducted experimental studies and the results of their processing, as an example, calculations of wood-waste balances (dry edged sawn timber) were carried out in the manufacture of four window units measuring $1,000 \times 1,000 \mathrm{~mm}$ from a threelayer glued bar of rectangular cross-section and from a three-layer shaped glued bar of complex cross-section.

The calculations were carried out for such structures: blank window unit; the window unit divided by transom-bar on a fixed leaf and a pivotal leaf; the window unit with two pivotal leafs; the window unit divided by transom-bar and two pivotal leafs. In a blind window unit, the glazing unit is fixed in a box with an internal profile as in the leaf. In the window unit, divided by transom-bar into a fixed leaf and a pivotal leaf, a double-glazed window in the fixed leaf at the bottom and top is additionally fixed with the help of a fixing bar and a filling rail, respectively.
The analysis of wood-waste balances (dry edged sawn timber) in the manufacture of window units of various designs showed that the percentage of the output of window unit parts from a three-layer shaped glued bar of complex cross-section, as compared to three-layer glued bar of rectangular cross-section, increases, in particular, for a blank window unit from 27.31 to $32.73 \%$, for a window unit divided by transom-bar into a fixed leaf and a pivotal leaf - from 22.99 to $29.87 \%$, for a window unit with two pivotal leafs - from 21.65 up to $28.66 \%$, for a window unit divided by transom-bar and two pivotal leafs - from 20.95 to 29.15 .

In general, the use of a three-layer shaped glued bar of complex cross-section for the manufacture of window units will save up to $25.56 \%$ of dry edged pine lumber.

Key words: three-layer shaped glued bar of complex cross-section; three-layer glued bar of rectangular cross-section; wood-waste balance; consumption of dry edged lumber; output of window unit parts. 